\title{
FROM METAL DETECTION FIELD SURVEYS TO COMMUNITY ARCHAEOLOGY IN BORSOD-ABAÚJ-ZEMPLÉN COUNTY
}

GÁBOR BAKOs ${ }^{1}$

Hungarian Archaeology Vol. 9 (2020), Issue 2, pp. 68-73, https://doi.org/10.36338/ha.2020.2.3

The importance of involvement by volunteers supporting museums in archaeology is on the rise, although fostering this support differs between counties, since there is still no uniform solution. The inclusion of private citizens with metal detectors or other expertise has become particularly significant in the last few years. Although the involvement of private individuals in archaeological work is not unprecedented, the large-scale cooperation of today is still quite new. The first attempts by the Herman Ottó Museum in Miskolc to execute its own interdisciplinary model started in early 2015. The experiment proved to be successful and developed into a continually improving, extremely effective project. The program continues to adapt and be shaped by opportunities, while striving to adhere fully to professional expectations. This article aims to present this process from two viewpoints, as the author - being the museum's archaeological field assistant - takes part in both the activities of the metal detection team, as well as planning and management, while also utilizing the field experience in future projects.

Public archaeology - involvement of private individuals in the work of museums - is in many ways a new phenomenon in our country. This is not an innovation in fact, since there are many examples from England (RenFrew, 2000; Bland, 2008) and France (LeCroere, 2016) of the involvement of volunteers in handling certain tasks. However, the practice has only started to spread its wings in Hungary, and professional opinions about volunteer archaeological labor differ region-by-region even though we live in a small country. Every museum that has started to utilize it in one form or another has tried to set up a system in accordance with its own needs and opportunities. The objective has been to gather enthusiastic private individuals who are curious about archaeology, while strictly adhering to the rules of the profession. This is appropriate, as the museums must determine directives that are the most suitable for their opportunities.

The presence of private individuals creates an advantageous situation for both parties. The archaeological field gains a kind of feedback, while also making its tasks quicker and smoother with the help of the volunteers. On the other hand, the people from outside the museum can gain a closer understanding of its everyday operation. They contribute to the work alongside professional guidance, helping to save our dying archaeological heritage.

Examples of this include the following: the project at Orosháza (BíRó et al., 2017) led by Gyöngyvér Bíró and Zoltán Rózsa, the initiative of Tibor Ákos Rácz in Pest county - operating on the level of an association - that is starting to extend beyond the boundaries of the county (RÁCz, 2019), and last but not least, the successful projects of the National Museum (HNM National Archaeological Program 2020).

The idea - based upon my own concepts - that provided the foundation for a large, complex, professionally-framed design began to unfold at the Herman Ottó Museum in Miskolc in 2015. A favorable situation emerged, as both the museum and the people interested in our work were open to discussion, which provided an opportunity to assess the common project. By chance, the Amersfoort program of the European Archaeological Committee also started in the same year (EAC, 2015), and one of the key elements of this is the integration of archaeology into society. The program's goals are to create a profile for future archaeological heritage management by focusing on special topics, to provide momentum to the Valletta Treaty that deals with the protection of archaeological heritage, and to carry out the Faro Convention, which deals with the societal value of our cultural legacy. The program tries to find a way 
to transform theories and practices in accordance with 21 th century archaeological practices and the needs of society (CoE \& EAC, 2019). This has been discussed at numerous conferences of the European Archaeological Committee (EAC).

Change in Hungary was advanced by the modification of laws, which altered the use of metal detection equipment significantly. Act LXIV of 2001 - regarding the use of metal detection equipment - was radically amended by the Parliament in 2014 (Csorba, 2016). Due to this, the use of this kind of equipment is forbidden without an official permit if it is not connected to professional practices. The conditions for official permits were modified in 2016 and 2018, but these amendments only provided specifications for the law formulated in 2014. Before this, museums with exploration rights could only provide opinions about the research plans of incoming requests within their jurisdiction. Now, the creation of a cooperation agreement between the museum and the applicants has become a condition for acquiring a permit.

The requests and discussions were positive from the very start, so we were looking forward to putting our ideas into practice. At first, only a handful of institutions participated and the project had an experimental nature. This situation was created due to several factors. A strong distrust of the museums had developed within metal detecting groups, and this was one of the many problems that needed to be solved.

The goal during the development of the program in Miskolc was to create a community, where private citizens who wanted to help the museum could work as a unified group. We did not use the example of any foreign models, but instead we worked together to form our own system. Catering to our local capabilities, this provided hope for future operations and started to dissolve the distrust in the private citizens who were still unsure. Ultimately, a model that is still the basis of the volunteer program was created with the support of Gábor András Szörényi and Tamás Pusztai.

I saw this collaboration as a long-term objective that would address several layers of society, to protect the archeological sites not only through our work but also by the information shared with the local communities. I tried to shape the work schedule in such a way that the copious amounts of energy invested by our volunteers would be utilized in the most useful manner. I conceived a professionally stable, adequately documented system, where the loss of information would not occur.

Several factors were considered during the model's development, such as the fact that most of our team is only free on weekends due to their full-time jobs. Our volunteers also have different levels of professional knowledge. A brief conversation is always conducted with our applicants, where they are encouraged to take part in one of our projects and try to work with us. In every instance, they are provided information on the basic tasks. This knowledge is refined in the field, where they are also assisted in acquiring the skills required to perform the tasks. In this way, integration into the system is more personalized.

There are several reasons for continuous professional presence. Every volunteer has a different type of instrument that is able to detect the presence of metal underground with a varying level of accuracy. The user's proficiency with their metal detection device is also very important. Thus, if a group of volunteers with mixed levels of knowledge and varying qualities of tools works in the same area, they can complement each other's efforts. Moreover, the quality of the detection and the documentation can be evaluated, thus providing them an opportunity to refine their methods and to learn from one another. In addition to this, professional coordination is quite important in the observation of the circumstances of discovering an object.

The areas or deposits that are the subject of our surveys are places that we cannot perform professional research on, either because of the lack of the funds or human resources. However, sometimes we also examine well-known sites or their surrounding areas, which are subject to heavy illegal excavation activities or robbing. In these cases, our main concern is to prevent further destruction and to save as many relics as possible. In addition, the assessment of damage and its documentation is also a priority, to prevent damage to archaeological features. In addition, we inform the locals about the goals of our searches and the differences between the activities of the museum and people who perform metal detection illegally.

At the beginning, it was necessary to decide whether to rely upon group projects organized by the museum or independent civilians operating individually. I came to the conclusion that teamwork is the most 


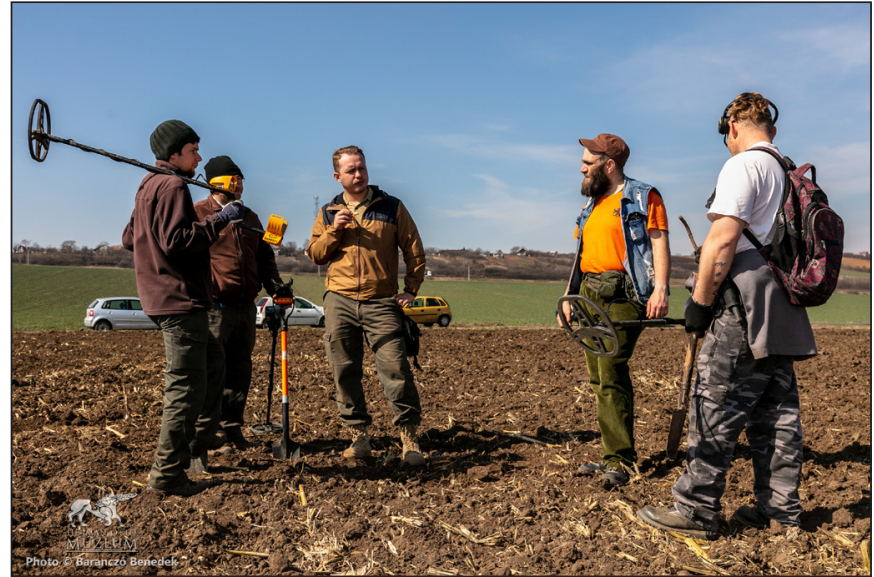

Fig. 1. Collective fieldwork

important element (Fig. 1). Accuracy and consistency - meaning thematic, organized searches - is what makes our work serious and useful. Reconnaissance work and metal detection sessions are not organized at sites that are not in imminent danger, and are not part of the museum's current research.

As with all museums, the proper professional documentation and restoration of copious amounts of archaeological finds from independent explorers would be a problem. Obtaining the enormous funds for the restoration of these relics is also quite important, as well as the forwarding of the documentation to the designated authorities. Since our financial support is limited, only preventive and targeted explorations are effective and manageable. The number of finds, and thus the cost of these activities, can be calculated by pre-planning the explorations (Fig. 2).

The documentation starts in the field by writing a field report, which contains all the necessary information in detail. This consists of the number of participants, the type of metal detection equipment they use, the description of the location, the environmental factors, the state of the soil and the general area as well as its level of endangerment. It is important to record the moisture level of the soil, as the metal detection equipment performs worse in dry, soft or freshly loosened soil. The location of finds is recorded with handheld GPS devices, and then they are placed in zip-lock bags. The location data, the number of the GPS device or the name of the finder, and the name of the site or location are listed on the bag. The documents accompanying the finds are written later, in an office environment, after the objects have been spread out and dried. They are often wet, which would make the documents next to them unreadable. The recorded points are accompanied by a track recorded by the GPS. During the geospatial processing, this helps to determine whether an inaccurate instrument, low object density or some other factor was responsible for the lack of finds in a given area.

Naturally, we want to involve our volunteers in more than just the fieldwork. One of our goals is for them to understand the everyday workings of our museum and to truly become part of its life. The days of investigation in the field are followed by processing the finds in the office. This way, our volunteers gain firsthand knowledge about the information we have obtained during the first step of our research. However, the role of the volunteers is not confined to the metal detection surveys and the packaging of the finds. They have also assisted us on numerous occasions with our events, at our excavations and during our field surveys.

At first, we only worked with 2-3 person groups, which made it easy to manage the coordination of

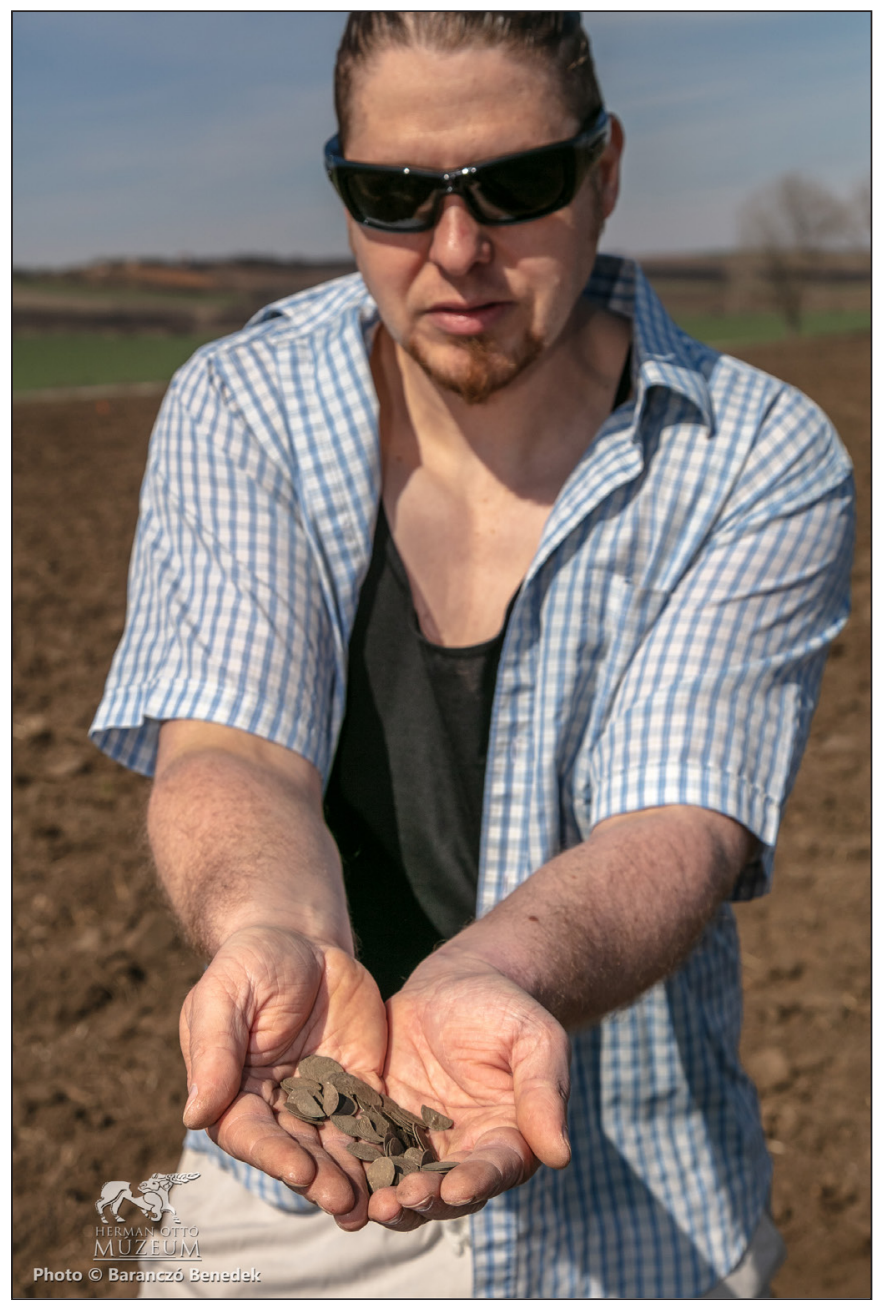

Fig. 2. Archaeological find in need of restoration 
tasks. The number of participants has grown continuously and has reached 60 people by 2020 . Such a large group needs strict organization, even more so if the research system previously planned out by the museum is used.

An educational program has been launched from the beginning of 2020 at the Herman Ottó Museum, where the volunteers are able to acquaint themselves with more than the finds from the different ages and the concepts of the different periods. Besides learning about archaeological eras, they can extend their knowledge with methodological concepts and a basic knowledge of topology, all of which can be used during their fieldwork in the future.

Teams from different locations often cooperate in the fight to preserve our common legacy. An example is the project to survey the battlefield at Mohács, which has met with increasing success every year (SzABÓ et al., 2017). This interdisciplinary research - led by József Laszlovszky- is guided by a similar concept, combining the private volunteers from several institutions and regions. Their goal in our county is to map the battlefield at Muhi. Naturally, the employees and private volunteers of the Herman Otto Museum are partners in this endeavor (LASZLOVSZKY, 2017). Moreover, our enthusiastic volunteers are active participants in a program led by Eötvös Lorand University, which deals with the investigation of Bronze Age strongholds and their depots. The impressive achievements of this endeavor show the usefulness of metal detection equipment in archaeology (V. SzABó et al., 2014).

\section{SUMMARY}

It is important to emphasize - as can be read on many forums and platforms - that metal detection searches and field surveys are not complex social archaeological programs. However, people who are curious due to the effect of these often contact the museums.

Our objectives in community archaeology are more than the inclusion of private individuals in our work. It is also to introduce our research and achievements to a wider audience. We must draw the attention of landowners and the local population to the cultural wealth around them, treasures that can be saved and interpreted with just a little bit of effort. From these sources, we can create a unified story that can effectively expand our knowledge about the everyday life of previous generations. In this way, we can take a new approach to archaeology, while also enriching the history of local settlements. By getting villages, towns and local civilians more interested in archaeology, the conservation of their heritage can gain a larger role in their lives. As a result of this initiative, the residents will feel more connected to their heritage. The likelihood of them contacting the authorities or the professionals upon discovering archaeological finds or witnessing their destruction will grow exponentially.

One of the leading institutions for the above activities is the Herman Ottó Museum in Miskolc, which is presently performing systematic research with more than 60 people. However, there is still no close coordination between the cooperation initiatives and the already existing system of projects, because everybody envisions their future in their own way. However, it is essential in the long term for the profession as a whole to open up to this topic (V. SzABÓ, 2009). Setting up a comprehensive uniform system is also necessary. This can be made more efficient on a national level through two-sided communication and the development of a common protocol.

The active collaboration projects currently work according to different sets of rules, and have not even started yet in some counties. The projects that already exist also have huge differences, as some give absolute freedom of action to the volunteers. Moreover, some archaeologists call in volunteers for their own projects and research, and work together with them on the field.

The social archaeological programs must also diverge from an object-based approach. Our common goal and strong determination are to unburden the museums, resulting in the creation of new publications, exhibitions and presentations. These are the actions that can bring people closer to understanding their past and the protecting their archaeological monuments.

This effort is at the beginning of a long road, fraught with a great deal of work and problems to solve. 
Gábor Bakos • From Metal Detection Field Surveys to Community Archaeology in Borsod-Abaúj-Zemplén County

The cooperation projects and other programs, continuous communication between institutions, exchange of information and correction of incomplete documentation are the goals that must be reached in the near future.

\section{RECOMMENDED LITERATURE}

Rácz, T. Á. (2017). Metal detector users affiliated to museums: Building a model of community archaeology in Pest County. Hungarian Archaeology 6 (3) [2017 Autumn], 1-7.

V. Szabó, G. (2019). Bronze Age Treasures in Hungary. In Search of Hidden Weapons, Tools and Jewellery. Budapest: Archaeolingua.

\section{BIBLIOGRAPHY}

Bíró, Gy. \& Rózsa, Z. (2017). The 15th and 16th century history of Orosháza. A travelling and temporary exhibition. Hungarian Archaeology 6 (2) [2017 Summer], 2-6.

Bland, R. F. (2008). The development and future of the Treasure Act and Portable Antiquities Scheme. In S. Thomas \& P. Stone (eds.), Metal Detecting and Archaeology (pp. 63-86). Woodbridge: The Boydell Press.

CoE [Council of Europe] \& EAC [Europae Archaeologiae Consilium] (2019). Strategy 21: Archaeological Heritage Management in Europe. https://rm.coe.int/strategy-21-archaeological-heritage-management-ineurope-in-less-than-/16808e9905 Accessed: 9 May 2020.

Csorba, Gy. (2016). Fémkereső müszerek [Tools used in metal detecting]. Infojegyzet 2016/20 [16 May 2016]. https://www.parlament.hu/documents/10181/595001/Infojegyzet 2016_20 femkeresok. pdf/2918a3d3-f10e-4d33-b036-12d6fe3852fe Accessed: 9 May 2020.

EAC [Europae Archaeologiae Consilium] (2015). Amersfoort Agenda - Setting the agenda for the future of archaeological heritage management in Europe. https://f64366e3-8f7d-4b63-9edf-5000e2bef85b.filesusr. com/ugd/881a59 867792b3d3ae40cba005bd026f43a006.pdf Accessed: 2020. május 9.

Laszlovszky, J. (2017). Metal-detector surveys in Hungary. New projects and results. Hungarian Archaeology 6 (2) [2017 Summer], 1.

Lecroere, T. (2016). "There is none so blind as those who won't see": Metal detecting and archaeology in France. Open Archaeology 2, 182-193.

HNM [Hungarian National Museum] (2020). Közösségi régészeti program [A community archaeology programme]. https://www.facebook.com/MNM-K\%C3\%B6z $\% \mathrm{C} 3 \% \mathrm{~B} 6 \mathrm{ss} \% \mathrm{C} 3 \% \mathrm{~A} 9 \mathrm{gi}-\mathrm{R} \% \mathrm{C} 3 \% \mathrm{~A} 9 \mathrm{~g} \% \mathrm{C} 3 \%$ A9szeti-Program-115976339811208/ Accessed: 9 May 2020.

Rácz, T. Á. (2019). Közösségi régészet. Egy új kutatási eljárás születése [Community archaeology. The birth of a new research method]. Múzeumcafé: a múzeumok magazinja 13 (4), 149-157.

Renfrew, C. (2000). Loot, Legitimacy and Ownership: The Ethical Crisis in Archaeology. London: Duckworth. 
Gábor Bakos • From Metal Detection Field Surveys to Community Archaeology in Borsod-Abaúj-Zemplén County

Szabó, M., Bertók, G., Gáti, Cs. \& Szajcsán, É. (2016). Mohács battlefield survey - The lessons learned from the first national archaeological metal detecting rally. Hungarian Archaeology 5 (2) [2016 Summer], $1-7$.

V. Szabó, G. (2009). Kincsek a föld alatt. Elrejtett bronzkori fémek nyomában [Treasures under the floor. Searching for hidden Bronze Age metals]. In A. Anders, M. Szabó \& P. Raczky (eds.), Régészeti dimenziók. Tanulmányok az ELTE BTK Régészettudományi Intézetének tudományos mühelyéböl. A 2008. évi Magyar Tudomány Ünnepe keretében elhangzott elöadások (pp. 123-138). Budapest: ELTE BTK Régészettudományi Intézet.

V. Szabó, G., Czajlik, Z.\& Reményi, L. (2017). Traces of an Iron Age armed conflict. Hungarian Archaeology 3 (1) [2014 Spring], 1-6. 